\title{
Are circular economy policies actually reaching organizations? Evidence from the largest Spanish companies
}

\author{
M. Marco-Fondevila*, F. Llena-Macarulla, S. Callao-Gastón, J.I. Jarne-Jarne \\ University of Zaragoza, Accounting and Finance Department, Spain
}

\section{A R T I C L E I N F O}

\section{Article history:}

Received 15 November 2019

Received in revised form

21 September 2020

Accepted 26 October 2020

Available online $\mathrm{xxx}$

Handling editor: Zhifu Mi

\section{Keywords:}

Circular economy

Listed companies

Environmental sustainability

EU CE Action plan

CE reporting

\begin{abstract}
A B S T R A C T
The Circular Economy (CE) model has recently gained a lot of attention as an effective way to cope with the urgent issues related to Climate Change and sustainability. The European Union (EU) has launched a series of reports, plans and activities known as the Circular Economy package which main goal is to expand the CE model throughout Europe, with large companies leading the initiative. This paper aims at assessing their engagement with the CE model, and if their actual understanding, practice and reporting of CE corresponds to the standards and principles promoted by the EU CE Action Plan. The research does also analyse if large companies' reporting in terms of CE can be assimilated to their environmental sustainability reporting or if they consider it a different topic, with different drivers. The reports of the largest companies in Spain (IBEX35) were studied in full detail as well as their environmental scores (ESG) from DataStream database, and activity sector. Results show interesting implications highlighting how companies' perception over CE, as reported, differs from the EU CE Action Plan approach and from the environmental sustainability framework, especially when taking into account the type of activity.
\end{abstract}

() 2020 Elsevier Ltd. All rights reserved.

\section{Introduction}

As stated by the European Commission, since the industrial revolution, our economies have developed a "take-make-consume and dispose" pattern of growth, a linear model based on the assumption that resources are abundant, available, easy to source and cheap to dispose of. However, the resource scarcity, depletion of non-renewable resources and environmental impact drive to an alternative economic model based on waste and resources cycling. Moving towards a more Circular Economy (CE) is essential to reach sustainable growth and requires changes in companies, markets, consumer behaviour and policies. The concern about the transition to a CE model is reflected in a growing interest of companies (Elia et al., 2017; Linder and Williander, 2017; Urbinati et al., 2017) and in the national and regional policies developed, for example, by China, Japan or the European Commission (EC) (Jones and Comfort, 2017; Mathews and Tan, 2011).

The academic research on $\mathrm{CE}$ is also increasing. The study by Ghisellini et al. (2016) provides an extensive and interesting

\footnotetext{
* Corresponding author.

E-mail addresses: mmacof@unizar.es (M. Marco-Fondevila), ellena@unizar.es (F. Llena-Macarulla), scallao@unizar.es (S. Callao-Gastón), jijarne@unizar.es (J.I. Jarne-Jarne).
}

literature review and classifies the reviewed searches according to the different subjects and perspectives: origins, basic principles, advantages and disadvantages, modelling and implementation (at micro, meso and macro level). Most empirical studies address CE in relation to specific topics, stakeholders (Pomponi and Moncaster, 2016), or industry segments (Lieder and Rashid, 2016). However, the common engagement of the private sector as a whole, regardless of every company or activity specific need, is still unknown, as well as if the consequent transition to a circular business model makes part of the private sector agenda or not. Geissdoerfer et al. (2017) did also review recent research on CE and focused on the similarities, differences and relationship between two important concepts, circular economy and sustainability. They found that most authors focus on the environmental performance improvements of the CE rather than taking a holistic view on all three dimensions of sustainability, and conceptually simplify the CE to resource input, waste and emission output. Other issues, like land use or biodiversity loss, are only implicitly addressed by some authors. The coverage of social wellbeing by most CE authors is also narrow. If social aspects are mentioned, the reference is mostly to job creation. For example, European Commision (2015) presents circular economic systems as beneficial for different sustainability dimensions like resource productivity, job creation and GDP growth. 
From the private sector perspective, both, environmental sustainability and CE commitments, policies and activities undergone by the companies, are transmitted to their stakeholders through reporting, mostly through CSR or sustainability reports. Nevertheless, to date, research on the incorporation of the main aspects of the $\mathrm{CE}$ into corporate information transmitted to the different economic and social agents, and its relationship with the environmental information reported, is very scarce (Lieder and Rashid, 2016). While most of the papers addressing the private sector uptake of CE focus on significant sectors or activities, the actual engagement of large companies with the concept of $\mathrm{CE}$, regardless of every company specific approach, is still understudied.

Continuing the work of Stewart and Niero (2018), the present study aims to know how the CE model is understood and reported by companies and to what extent it is treated as a different topic than environmental sustainability. With a sample of Spanish companies, specifically those listed in IBEX35 at December 2018, which represent a heterogeneous group of the largest companies in the country, we include a focus on different industries in order to compare the presence and effects of the CE depending on the sector to which the company belongs. The Spanish largest companies, as well as all other European Union large companies, are expected to take the lead of the Circular Economy Action Plan launched by the EU in $2015^{1}$, promoting policies and specific actions to adopt the CE model within the corporate strategy. The weight of the Spanish economy within the EU (fourth in the Euro area), with $9.1 \%$ of the EU28 total population, together with the political impulse given to the $\mathrm{CE}$ by the Government, place Spain in a good position to aspire becoming an international benchmark in the implementation of the CE. As in other European countries, the Spanish Circular Economy Strategy for 2030 has been drawn up, laying the foundations for promoting a new production and consumption model in which the value of products, materials and resources are maintained in the economy for as long as possible, while waste generation is minimized and/or used to the greatest extent possible. Likewise, it is important to point out that Spain has been the first country in the EU28 establishing specific objectives for preparing re-use, both in the regulations on electrical and electronic equipment waste, and in vehicles at the end of their useful life, including municipal waste (MINEICO, 2018). On the other hand, the particularities of the business sector in Spain: relatively small size of companies, corporate governance composition with less independent participation than in other countries; and/or the ownership structure, in many cases family based, makes it interesting to investigate how companies in this country are incorporating the concept of CE. Aware that CE must be initiated and led by the largest companies (European Commision, 2015), we focus on Spanish companies listed on the IBEX35, trusting the traction effect of these companies over the whole business sector.

Since corporate sustainability report is the main vehicle for communication through which companies do transmit to stakeholders their core ideas and progress on CE and environmental sustainability, we selected the 2017 reports, being the first one in which the CE Action Plan may have had a visible impact, after two years of its launching. The 2017 sustainability, CSR and/or annual reports of every one of the sample companies were therefore analysed in full detail.

We reviewed the specific references to $C E$ together with the

\footnotetext{
1 The European Commission has proposed to ensure the maximum impact of the CE concept and has set up an enabling policy framework. In 2015, the Communication entitled "Closing the loop: an EU action plan for the Circular Economy" (COM (2015) 614 final) proposes different actions regarding production, consumption and waste that constitute the framework for member countries.
}

actions reported and the alignment with the actions proposed by European Commision (2015) regarding production, consumption and waste. These actions constitute the framework for member countries in the European Union (EU), in which the companies in the sample are working.

The paper contributes to the research on the uptake of CE by large companies by reviewing the actual incorporation of the concept to the external corporate information and its relationship with environmental sustainability. Our findings should not be understood as the extent to which companies have adopted CE, which is extremely hard to measure and assess, given its voluntary character and its close relationship to the specific activity of the company. Although a company may seek to please its stakeholders by pretending to be circular through the information provided without actually improving its performance, we believe that a company that provides more information on $\mathrm{CE}$ is more prone to be circular than a company which does not so.

The rest of the paper is organized as follows. In the next section, we provide the background and the research questions derived from it. The sample and methods are explained in section three. The results are presented in section 4 , and, finally, we highlight our main conclusions.

\section{Background}

CE is an economic model that involves the incorporation of several principles in business operations that can promote better use of materials, resources and products. In accordance to the Ellen MacArthur Foundation (2013) and the European Commision (2015), it can be defined as an economic model that is restorative and regenerative by intention and design, looking for products, components, materials and resources to maintain its usefulness and maximum values at all times and as long as possible, minimizing the generation of waste. The $\mathrm{CE}$ is based on several basic principles initially called the $3 \mathrm{R}$ (reduce, re-use, recycle), that have been expanded to others such as recover, remanufacture, repair, rethink, etc. (Kirchherr et al., 2017; Potting et al., 2017). A description of the changes proposed in confrontation to the current linear model could be: "CE aims to design out waste, replaces end-of-life concept with restoration, uses renewable energy, eliminates the use of toxic chemicals, etc., and aims for the elimination of waste through the top design of materials, products, systems" (Ellen MacArthur Foundation, 2013). In this sense the European Commision (2015), which has assumed the promotion of $\mathrm{CE}$ as a key axe, puts the focus of actions in various aspects of economic systems where the activities of CE should play a fundamental role about materials and resources, products, consumption, etc. The companies' adoption of $\mathrm{CE}$ has been seen as a change of paradigm, requiring specific skills and capabilities (De los Rios and Charnley, 2017). The latter may be studied after the framework and dimensions in which we focus the CE new business model (Urbinati et al., 2017), the intensity of 'loops' (Geissdoerfer et al., 2018), or the main archetypes of CE business models (Rosa et al., 2019), among other possibilities. Nevertheless, the conceptualization and actual framing of CE is still a matter of debate, as shown by Prieto-Sandoval et al. (2018).

The European Commision (2015) in its action plan for the circular economy named "Closing the loop", states that this plan must contribute to reach the United Nations Sustainable Development Goals, in particular the 12th goal: Sustainable consumption and production. For this purpose, it proposes several basic lines of preferential action, based on the point of view of the entire life cycle of the products, such as the product design and production process phases that have a relevant impact in resources use and waste generation. The EU Action Plan has also a focus in improving information for consumers about durability, reparability, re-use, 
environmental footprint, and other preferred areas of action due to their environmental impact such as waste management, secondary raw materials and water re-use. Furthermore, areas like plastics, food waste, critical raw materials, construction and demolition, biomass and bio-based products, and innovation are treated as priority targets (European Commision, 2015). Most of these areas have been traditionally considered as environmental sustainability goals, or even sustainable development goals, thus contributing to the confusion about the boundaries and overlapping of each concept, bringing in 'paradoxical tensions' (Daddi et al., 2019) and simultaneous competing sustainable goals (Hahn et al., 2017).

\subsection{CE and sustainability relationship}

Sustainability is the expression of the business activity impact on the triple bottom line, the commitment with or the capacity to achieve sustainable development (AECA, 2003). According to Gallopin (1994), the concept of sustainable development implies an idea of change and actions to achieve a purpose, while sustainability is more frequently associated with the maintenance of a system or a particular situation that is considered desirable. It could be said that, through sustainable development, the system sustainability is pursued.

Different studies have studied the relationship between CE and sustainability to determine their differences and similarities (Geissdoerfer et al., 2017; Kirchherr et al., 2017; Ghisellini et al., 2016; Sauvé et al., 2016; Stewart and Niero, 2018), in light with the recent interest shown by policymakers, practitioners and scholars. Furthermore, the institutional approach to $\mathrm{CE}$, for which the EU Action Plan can be considered a representative case, has been challenged as being too much oriented towards technology and production, leaving aside relevant factors such as sociopolitical and consumption patterns (Schulz et al., 2019). While Geissdoerfer et al. (2017) and Stewart and Niero (2018) conclude that sustainability and CE are not substitute nor equivalent concepts, Sauvé et al. (2016) believe that CE is a model of production and consumption that helps achieve sustainable development. Consequently, it may be considered an economic model that is part of the environmental perspective of sustainability, where the activities of CE may be actions that will help achieve greater sustainability.

Some authors discuss if CE is a new paradigm of sustainability (Geissdoerfer et al., 2017), while others regard it as an economic model that contributes to achieving sustainability (Ellen MacArthur Foundation, 2013; Ghisellini et al., 2016). In this sense, Geissdoerfer et al. (2017) consider different relationships between the concepts of sustainability and CE: conditional, beneficial or trade off relationship. Conditional relation means that $\mathrm{CE}$ is one of the conditions for a sustainable system; beneficial relation means that CE helps achieve sustainability, but is not a condition to do so, and trade off relation indicates the CE could benefit some aspects of sustainability and harm others. These authors discuss the main differences and similarities between the various proposals, while Stewart and Niero (2018) use this classification to study the relationship between CE and sustainability in CSR reports.

The results of the analyses indicate that, in general, companies do not show a clear relationship between CE and sustainability, and that $C E$ "seems to be considered as a purpose to be pursued per se in many reports" (Stewart and Niero, 2018, p 1010). Consequently, as of now, it is not clear if CE could be considered as an economic model that is part of the environmental perspective of sustainability, and whose activities promote the achievement of sustainable development through a change in the management model. Regarding the empirical research about the uptake by private companies of those two concepts, and their transmission to their stakeholders through reporting, the environmental and sustainability information and accounting have been widely studied in the literature of recent decades (Deegan, 2002; Larrinaga et al., 2002; Llena et al., 2007, 2015; Marco-Fondevila et al., 2018). Multiple works analyse the activities linked to the concept of sustainability and the transparency and reporting associated with it, both from a qualitative and a financial perspective (Bebbington et al., 2014; Deegan, 2002). On the other side, several works have analysed the implementation of the principles and activities of CE in companies and organizations (Bocken et al., 2017a,b; Ghisellini et al., 2018; Katz-Gerro and López-Sintas, 2019; Stewart and Niero, 2018), as well as the relationship between the different ways of practicing CE and management control in companies (Svensson and Funck, 2019).

One of the most important compilations of CE research is that of Ghisellini et al. (2016), which consists of a review investigating different types of $\mathrm{CE}$ activities, classifying them according to the principles of the CE: Design, Reduction, Re-use, Recycle, and Reclassification of materials into Renewable Energy. Stewart and Niero (2018) explore the Corporate Sustainability reports of 46 companies in the Fast-Moving Consumer Goods industry, concluding that the analysed companies in that precise sector, link CE with primarily environmental and economic aspects, ignoring the social dimension. The main environmental aspects are resource scarcity, climate change and environmental pressures. In addition, most of the activities reported are based on products and their packaging, focusing on end-of-life management and sourcing strategies, as well as on circular product design and business model strategies. In addition, Bocken et al. (2017a,b) carried out a case study in a large international clothing retailer. Although they observed the intent of developing sustainable practices related to circularity, these were still emerging and repetitive, and circular business models coexisted with non-circular models. Aranda-Usón et al. (2019) analyse the availability of funds, the quality of the firm's own financial resources and the public subsidies as drivers to the implementation of $\mathrm{CE}$ activities in 87 Spanish companies of various sectors, while Portillo-Tarragona et al. (2017) and Moneva et al. (2018), analyse the progressive implementation of CE principles in companies, depending on the activities performed.

From a more theoretical perspective, Katz-Gerro and LópezSintas (2019) carried out a mapping of CE activities based on the Eurobarometer 2016 survey to the group of SMEs of EU 28 countries. These authors classify the SMEs behaviour in seven patterns according to the CE activities and the companies' characteristics. They conclude that there is interdependence between the CE activities, from highest to lowest probability of implementation: waste minimization, replanning use energy, redesigning products and services, renewable energy and replanning water usage. While Prieto-Sandoval et al. (2019) identify the strategies and resources needed to apply CE in SMEs, Urbinati et al. (2017) developed a new taxonomy of CE business models among a group of 86 companies from various sectors having implemented the CE principles to a different extent. This taxonomy defines four models for the adoption of the CE postulates, which allows classifying companies from Full Circular, Upstream and Downstream Circular, to linear model.

Despite the growing number of investigations about $\mathrm{CE}$, the empirical research addressing the actual linkage between $C E$ and environmental sustainability in companies from various sectors, is still rather scarce, according to the existing compilations and classifications of CE studies and their relationship with sustainability (Elia et al., 2017; Geissdoerfer et al., 2017; Ghisellini et al., 2016; Urbinati et al., 2017). 


\subsection{Theoretical approach}

Researchers have used different theories to explain social and sustainability behaviour of companies. Various exogenous variables (stakeholders, social and economic context, etc.) and endogenous factors (own resources, employees, etc.) may influence the companies' behaviour, suggesting different theories (Portillo-Tarragona et al., 2018). The exogenous variables would relate to the stakeholders' theory, the institutional theory (Scott, 2014) or even to the legitimacy theory (Deegan, 2017; Gray et al., 2018; Schaltegger and Burritt, 2017). The Resource Based View (RBV), on the contrary, would focus on endogenous elements of the company, as resources and capabilities (Barney, 2001b; Barney and Arikan, 2008; Bromiley and Rau, 2016; Lockett and Thompson, 2001; Wernerfelt, 1984). The theories based on exogenous variables highlight the social component of companies, which are accountable for their actions. In this context, the institutional theory would explain the companies' behaviour after their disclosure standards about their activities in the field. This theory would justify the companies' behaviour through the existence of different forces (mechanisms) leading to specific actions (Campbell, 2007; DiMaggio and Powell, 1983; Scott, 1995, 2014). While DiMaggio and Powell (1983) call them mechanisms of institutional isomorphism, Scott (1995; 2014), Higgins and Larrinaga-González (2014) and Acerete et al. (2019) classify them in coercive, normative and mimetic-cultural mechanisms.

The coercive and normative pressure comes from mandatory elements (regulations) establishing norms in the company environment (sector, association, etc.). The public and private regulation, as the EU Action Plan for CE, can be considered drivers for companies' behavior (Acerete et al., 2011, 2019). The mimeticcultural mechanisms materialize when companies imitate the actions of other entities with which they have some degree of similarity or common cultural factors, in order to justify their good behavior (Gallego-Álvarez and Ortas, 2017; Haniffa and Cooke, 2005; Zaman Mir et al., 2009). Several papers analyse the companies' sustainability behavior drivers through the analysis of their disclosure standards as proxy for their actions (Clarkson et al., 2008; Llena and Talalweh, 2015; Qiu et al., 2016; Marco-Fondevila et al., 2018). However, to date, there is a gap in linking this analysis to the circular behavior of companies, studying the interaction of companies' CE activities and their disclosure standards.

The RBV theory focuses on the resources and capabilities of companies as explanatory factors of their actions (Barney, 1991; Barney and Arikan, 2008, Lockett and Thompson, 2001; PortilloTarragona et al., 2018). Some researchers have extended the theory to the Dynamic Capabilities-Based perspective, focusing on the ability of companies to adapt their strategies in changing environments (Barreto, 2010; Cepeda and Vera, 2007; Scarpellini et al., 2020; Teece et al., 2009). For instance, Portillo-Tarragona et al. (2018) analyse the specific resources and capabilities applied to the eco-innovation investments in different companies of diverse industries. In this sense, the direct relation between company size and the access to larger financial and material resources as well as to professional skills and training, justify the selection of large listed companies as sample for research (Aranda-Usón et al., 2019).

To date, however, it is not clear which theoretical approach, whether exogenous or endogenous, better explains the companies' behavior in terms of adopting and practicing CE. This paper aims at contributing to this debate by assessing if the largest companies in Spain show an institutional or legitimacy response to the EU Action Plan, or else their approach to CE is based in endogenous factors such as differentiation and competitive advantage (in line with RBV theory).

\subsection{Institutional context}

In Europe, the extensive promotion and publicity given during the last few years to the EU Circular Economy Action Plan, together with the projects and actions supported by the Plan, may have had a recent impact in the companies' degree of involvement and adoption of the CE model. As stated in by the European Commision (2015), large companies are expected to lead the transition to a more circular model, and thus, they should be the ones reporting more information about it in their reports. However, given that the Action Plan was launched only in 2015, and that companies usually require some time to adopt, measure and report their moves, it is not likely that the institutional impulse to $\mathrm{CE}$ derived from the Action Plan could be observable in reports prior to 2017. In fact, Bocken et al. (2017a,b) explored the incorporation of the CE concept among 500 listed companies in a 10-year period from 2005 to 2014, concluding that the concept was not used in any corporate communication of the analysed sample, although the main circular ideas were present in areas like maintenance, recycling, refurbishing and managing waste.

Assessing the impact that the CE Action Plan is having in large companies appears to be of interest for officials, scholars and policy makers, as well as for practitioners and companies themselves, as a measure of benchmarking in competition and corporate reputation. Furthermore, assessing if companies are interested in the CE model, only that with a different understanding that of the EU proposal regarding what it implies and where it is relevant for the company, could be rather useful to adapt the Action Plan initiatives, adjust the communication actions and/or rethink the whole Plan and future policies. As a EU member, subject to the Action Plan, Spain has shown a notable interest in the CE model, both at public level (CE strategy for 2030), and among private companies (COTEC, 2017). The IBEX35 stock index, representing the largest companies in the country, makes a sound sample of companies from diverse sectors of activity, with different management models, and a varied range of inclinations towards sustainability.

Aiming at assessing if the CE Action Plan has had an impact in companies' reports, and to what point is CE seen by the latter as part of the wider field of environmental sustainability; several categories of $\mathrm{CE}$ have been selected, establishing the different variables to be researched, analysed and discussed. In this sense, we classify such activities adapting the structure proposed by the EU communication (2015) with three main phases or stages: process inputs, business processes and business outputs, which are connected to consumption, production and waste. The research questions proposed in this paper in order to answer the mentioned debates are the following ones: CE?

RQ1: Are Spanish largest companies engaged in the EU goals for

RQ1.1: Is the concept of CE part of the largest Spanish companies' agenda?

RQ1.2: Do Spanish largest companies understand CE the way the EU Action Plan proposes?

RQ2: Do Spanish largest firms assimilate CE to environmental sustainability?

Although RQ2 may appear speculative, it is worth it analysing if companies do understand $\mathrm{CE}$ as a distinctive field, related to environmental sustainability or, on the contrary, they see it as topic belonging to the environmental sustainability sphere, such as with biodiversity, for instance. This outcome could result in a valuable contribution for policy-makers and CE future programmes. 


\section{Methods}

\subsection{The sample}

The research sample is the Spanish IBEX35 stock index, as widely accepted representation of the 35 largest Spanish companies. However, 36 companies belonging to seven major activity sectors were included in the research, since both a company leaving the index in 2018/2019 and another one entering it in its place were included in the sample.

Since the analysis of companies' behaviour per sector is limited by the size of the sample, a new classification was defined according to three major features of the CE: use of resources, process and products. For each one of these features, an aggregated and representative indicator that would reflect the company behaviour was selected, out of the available information in the company's report. Energy intensity for resources (as one of the most relevant resources in terms of impact), emissions intensity (representing the environmental impact of the companies' process), and waste and effluents intensity (representing the impact linked to products), are the three representative indicators selected. Since all three indicators count on GRI specific indicators included in the companies' reports, a sound classification was obtained, allowing to a comparative analysis after their specific data in every aspect. For each feature, the companies were grouped in high or not high attending to the indicator intensity, as shown in Table 1.

Two main sources were used to gather the necessary data from the sample companies. The first one was the information publicly transmitted by the companies through their reports according to their accountability standards; and the second one was the DATASTREAM database, specialized on collecting and analysing corporate data related to the economic, social and environmental activity of companies. The companies' names, activity sectors and intensity in all three aspects of CE (energy, emissions and waste-effluents), are presented in Annex 1.

\subsection{The research}

Our first objective to answer the first research question (RQ1.1) is assessing if CE makes part of the largest Spanish companies' agenda as such. To this end, as a preliminary approach, we studied the companies' reports and checked the references specifically linked to $\mathrm{CE}$, considering all terms and words that could be related to $\mathrm{CE}$ (circularity, circular model, non-linear, closing-the-loop, and derivative terms). Next, we calculated the average references for the total of companies and per sector. Although this superficial analysis does not talk about the importance given to CE by companies, it gives a first insight about the interest generated by the term. Additionally, we assessed the relevance given to $\mathrm{CE}$ by the company, looking at the specific section of the report in which it appears, thus ranking the weight of such references (Fig. 1).

The second objective (RQ1.2) is determining if the Spanish largest companies are specifically engaged with the EU goals and standards for $\mathrm{CE}$, using as main source of information the data publicly reported by each company. The EU Action Plan (European European Commision, 2015) sums up most of the main variables considered in the literature (De los Rios and Charnley, 2017; Geissdoerfer et al., 2017; Ghisellini et al., 2016; Kirchherr et al., 2017; Lieder and Rashid, 2016). Therefore, we selected the variables shown in Table 2 to conform the 'EU Action Plan Circularity index' (EUAC) in our current empirical research, which assesses the companies' actual alignment with the EU CE approach. Whether the companies expressly consider it CE or not, the alignment is defined by the presence of information and data of the chosen variables, thus determining the actual engagement with the CE model proposed by the EU, rather than a formal declaration. The variables are grouped in three blocks referred to its nature as resources $(R)$, process $(P)$ or products $(\mathrm{Pt})$.

The method selected to calculate the EUAC index is not based on a quantitative approach, but on a qualitative one, which accounts firstly for the presence or not of the variables analysed, and secondly for its specific linkage to CE. The criterion adopted to build in the index considers the three following possibilities for every variable:

- No presence of the variable (None)

- The variable is present but it is not specifically considered as CE (EUAC)

- The variable is present and specifically considered as CE (CRC)

When the case is 'None', there is not alignment with EU goals, whatsoever. On the contrary, when the case is EUAC or CRC, the company is aligned with EU for this variable, whether without considering it CE (EUAC) or specifically considering it CE (CRC). Consequently, the CRC cases are embedded in the EUAC cases.

After assessing the presence of the twelve selected variables in every company's report, an aggregated indicator per group (EUAC_Resources [ $\left.\mathrm{R}_{1-4}\right]$, EUAC_Process [ $\left.\mathrm{P}_{1-4}\right]$, and EUAC_Products [ $\mathrm{Pt}_{1-}$ 4]) as well as a total indicator (EUAC) for the whole 12 variables, was obtained, determining the EUAC degree per company. A dichotomous score of ' $1-0$ ' was given for presence/no presence of the variable. The group and total indicators were calculated as an average of scores, thus ranging from ' 0 ' to ' 1 '. In order to safeguard the reliability of the empirical evidence and the possibility of bias due to subjectivity, the Cronbach's Alpha coefficient was calculated for every one of the four indicators (EUAC_R, EUAC_P, EUAC_Pt and EUAC).

In order to explore what Spanish largest companies themselves

Table 1

Intensity after GRI indicators for energy, emissions and waste-effluents.

\begin{tabular}{|c|c|c|}
\hline \multicolumn{3}{|l|}{ GRI Indicators } \\
\hline $\begin{array}{l}\text { Energy } \\
\text { - Energy consumption within } \\
\text { the organization } \\
\text { - Energy consumption outside } \\
\text { of the organization } \\
\text { - Energy intensity }\end{array}$ & $\begin{array}{l}\text { Emissions } \\
\text { - Direct greenhouse gas (GHG) } \\
\text { emissions (Scope 1) } \\
\text { - Energy indirect greenhouse gas } \\
\text { (GHG) emissions (Scope 2) } \\
\text { - Other indirect greenhouse gas (GHG) } \\
\text { emissions (Scope } 3 \\
\text { - Greenhouse gas (GHG) emissions } \\
\text { intensity } \\
\text { - Emissions of ozone-depleting } \\
\text { substances } \\
\text { - NOx, SOx, and other significant air } \\
\text { emissions }\end{array}$ & $\begin{array}{l}\text { Waste and effluents } \\
\text { - Total water discharge by quality and destination } \\
\text { - Total weight of waste by type and disposal method } \\
\text { - Total number and volume of significant spills } \\
\text { - Weight of transported, imported, exported, or treated waste deemed hazardous, and } \\
\text { percentage of transported waste shipped internationally }\end{array}$ \\
\hline
\end{tabular}




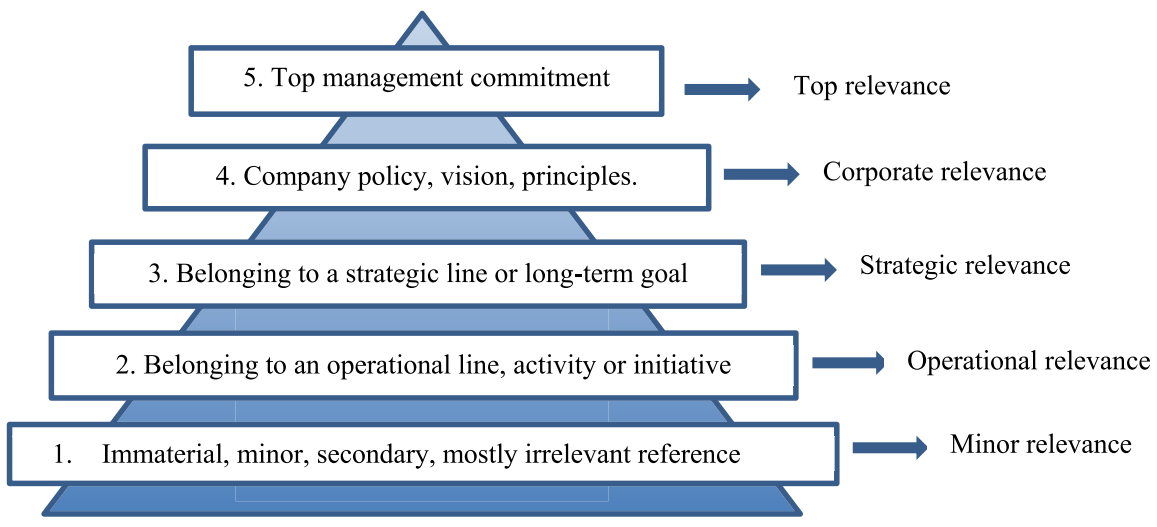

Fig. 1. Relevance of companies' CE references.

Table 2

EU Aligned Circularity variables.

\begin{tabular}{|c|c|c|c|}
\hline Nature & Research Variable & Definition & Condition \\
\hline \multirow[t]{4}{*}{ R. Resources } & $\begin{array}{l}\text { R1. Secondary raw } \\
\text { materials }\end{array}$ & Secondary or recycled raw materials are used in the process & $\begin{array}{l}\text { Make part of the company's total } \\
\text { raw materials }\end{array}$ \\
\hline & R2. Life Cycle Analysis & $\begin{array}{l}\text { Inputs and materials are selected after a Life Cycle Analysis to improve its environmental } \\
\text { impact }\end{array}$ & $\begin{array}{l}\text { Performed to select/prioritize } \\
\text { inputs }\end{array}$ \\
\hline & R3. Renewable energy & The company counts with renewable energy facilities, or uses renewable energy sources & $\begin{array}{l}\text { Make part of the energy used by the } \\
\text { company }\end{array}$ \\
\hline & $\begin{array}{l}\text { R4. Low environmental } \\
\text { impact }\end{array}$ & The company invests in decreasing its own overall environmental impact & $\begin{array}{l}\text { Performed to select/prioritize } \\
\text { inputs }\end{array}$ \\
\hline P. & P1. Energy efficiency & Substitution or improvement of equipment to decrease energy consumption & Promoted/pursued in the processes \\
\hline \multirow[t]{3}{*}{ Process } & P2. Dematerialization & The product/services design looks for decreasing the use of materials and resources & Promoted/pursued in the processes \\
\hline & P3. Industrial symbiosis & $\begin{array}{l}\text { The company shares processes, facilities, equipment, etc., to reduce waste and consumption, } \\
\text { and takes profit of synergies. }\end{array}$ & Promoted/pursued by the company \\
\hline & P4. Waste management & The company fosters and manages the recycling of the generated waste & $\begin{array}{l}\text { Specific goal, beyond Law } \\
\text { compliance }\end{array}$ \\
\hline & Pt1. Eco-design & The company undertakes environmental R\&D to achieve eco-innovative products/services & Promoted/pursued by the company \\
\hline \multirow[t]{3}{*}{ Products } & Pt2. Recyclability & The capacity of recycling is included in the products/services design & Promoted/pursued by the company \\
\hline & Pt3. Durability & The products/services design looks for extending the products/service lifetime & Promoted/pursued by the company \\
\hline & $\begin{array}{l}\text { Pt4. Low carbon } \\
\text { emissions }\end{array}$ & $\begin{array}{l}\text { The company designs products and services looking to decrease their associated carbon } \\
\text { emissions }\end{array}$ & Promoted/pursued by the company \\
\hline
\end{tabular}

specifically consider CE, we assessed the 'Companies' Reported Circularity' index (CRC), based on a qualitative analysis of the information explicitly reported by the companies as CE, which may or may not coincide with the EU proposal of CE. Again, when the selected variable is not expressly tagged as CE, the score is ' 0 ', while if it is, the score is ' 1 '. Aggregated indicators per group (CRC_Resources [ $\left.\mathrm{R}_{1-4}\right]$, CRC_Process [ $\left.\mathrm{P}_{1-4}\right]$, and CRC_Products [ $\left.\left.\mathrm{Pt}_{1-4}\right]\right)$, as well as in total (CRC) were obtained. While the EUAC results bring in the picture of companies' actual engagement with $C E$ as proposed by EU Action Plan, the comparison between the results obtained for EUAC indicators and CRC indicators shows to what degree the idea of CE held by companies is similar or aligned with that of the EU Action Plan (Fig. 2).

To assess if the company's type of activity influences the eventual differences between EUAC and CRC among the seven sectors included in the sample, and after confirming they do not follow a normal distribution, we used the Kruskal-Wallis non-parametric test. Furthermore, we tested if there were significant differences between EUAC and CRC after their intensity in energy, emissions and waste-effluents, using the Mann-Whitney non-parametric test. In order to fully compare the results obtained for EUAC and CRC, we carried out correlation analyses between them, both at aggregated level (the twelve variables together) and for each one of the three categories (resources, process and product).

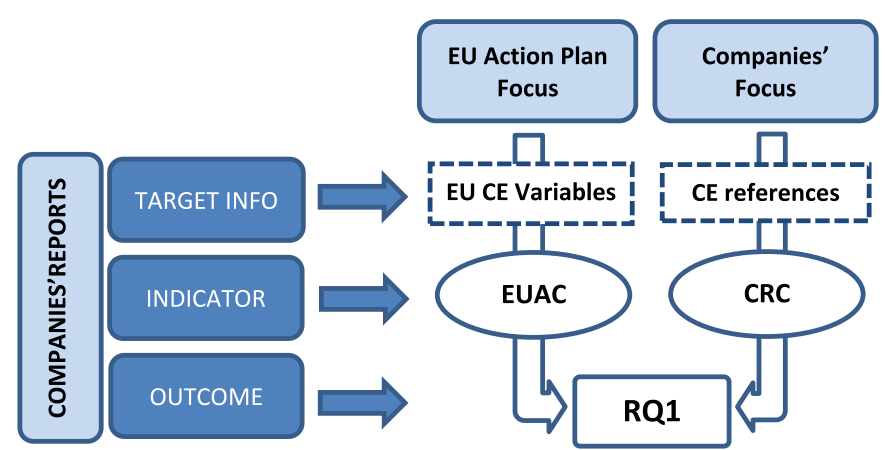

Fig. 2. Research method for RQ1.

To answer the second research question (RQ2), we evaluated the CE correspondence or relationship with environmental sustainability. For this purpose we used the 'environmental sustainability' index calculated and offered by the recognised DATASTREAM database (ESG_Env), ${ }^{2}$ which must not be confused with the 'sustainability' index, since the latest considers social and economic

\footnotetext{
${ }^{2}$ The variable code in DATASTREAM is ENVSCORE
} 
Table 3

Discrete results for CE references.

\begin{tabular}{|c|c|c|c|c|}
\hline Number of references & $\%$ of companies & Sector & Average references per sector & Std. Deviation \\
\hline None & $44.44 \%$ & (1) Industry & 8.75 & 11.2 \\
\hline From 1 to 5 & $27.78 \%$ & (2) Transp./logist. & 0.00 & 0.0 \\
\hline From 6 to 15 & $11.11 \%$ & (3) Technology & 9.75 & 19.5 \\
\hline From 16 to 30 & $8.33 \%$ & (4) Fin. services & 0.50 & 1.2 \\
\hline \multirow[t]{5}{*}{ More than 30} & $8.33 \%$ & (5) Manuf./retail & 8.75 & 17.5 \\
\hline & $100 \%$ & (6) Energy & 9.00 & 7.9 \\
\hline & & (7) Services & 2.20 & 3.3 \\
\hline & & Average per sector & 5.56 & \\
\hline & & Average per company & 6.14 & \\
\hline
\end{tabular}

Table 4

Discrete results for CE references relevance.

\begin{tabular}{|c|c|c|}
\hline Relevance & Companies references & \\
\hline Minor relevance (1) & 18 & Average relevance given \\
\hline Operational relevance (2) & 14 & \\
\hline Strategic relevance (3) & 12 & \\
\hline Corporate relevance (4) & 12 & \\
\hline Top relevance (5) & 5 & \\
\hline
\end{tabular}

Table 5

CE references relevance per sector.

\begin{tabular}{|c|c|c|c|c|c|c|c|c|}
\hline & (1) Industry & (2) Transp./logist. & (3) * Technology & (4) Fin. services & (5) Manuf./retail* & (6) Energy & (7) Services & TOTAL \\
\hline Average & 1.66 & - & 2.00 & 1.20 & 3.00 & 1.57 & 0.95 & 1.55 \\
\hline St. Deviation & 1.1 & - & 1.0 & 0.5 & 1.5 & 0.9 & 1.4 & 1.06 \\
\hline
\end{tabular}

variables. Besides its aggregated form, the 'environmental sustainability' index is also segmented in three subcategories: Resource Use Score (ESG_R), Emissions Score (ESG_E) and Environmental Innovation Score (ESG_I). We used the last four years' average scores to minimize the influence of abnormal data of any particular year. Next, we calculated the median for the different indexes (EUAC, EUAC_R, EUAC_P, EUAC_Pt, CRC, CRC_R, CRC_P, CRC_Pt) and divided the sample in two sub-groups: value above or below the median. Then, we used the Mann-Whitney non-parametric test to assess if there were significant differences between the environmental ESG indexes among the two sub-groups of companies.

\section{Results and discussion}

\subsection{CE presence in reports and relevance}

The first outcome from the analyses refers to the presence and relevance CE has among IBEX35 Index companies (RQ1.1). Throughout the study of the companies' reports, the following data about the number of references specifically linked to $C E$, were collected (Table 3):

Almost half of the companies had no specific reference to CE in their reports, being the transport \& logistic sector, the financial services sector and the services sectors, those with lower number of references. Especially relevant appears to be the transport and logistic sector, where no reference was observed whatsoever, although the low number of companies in that sector limits the statistical value of the result. The same limitation is applicable to the high average number of references observed in the technology and manufacture/retail sectors, where a single company with very high number of observations has a disproportionate impact in the sector average, as reflected by the high standard deviation.

The study of relevance given by companies to $C E$ after the positioning of references throughout the reports, was ranked through five categories from top relevance (top management commitment), to minor relevance (casual, not connected references), as previously shown in Fig. 1. Most companies giving top or corporate relevance to $\mathrm{CE}$ will also give strategic and operational relevance, since their top commitment will permeate to CE programs and/or projects. The average relevance for all 20 companies including specific references about CE is half way between 1 and 2, meaning 'somewhere in the way' to projects/activities related to CE (Table 4).

As for sectors, once discarded the transport \& logistics, where no references were observed, those with highest average are Manufacture/retail and Technology, again, highly affected by the single outstanding company belonging to each one of those sectors (Table 5).

The results obtained up to this stage are not statistically representative due to the small size of the sample and the subsequent influence that some companies have in the overall average. However, it brings in some interesting observations from a descriptive standpoint:

- Almost half of the companies belonging to the IBEX35 index have no reference of CE in their corporate public reports.

- The four top scorers in number of references belong to four different sectors

- The energy and industry sectors are the most homogeneous ones in number of references, with all companies mentioning CE at one stage or another.

- The transport/logistics and services sectors appear to be the least interested in $\mathrm{CE}$, with only one company referring to it among the two sectors' sample. 


\subsection{EU Aligned Circularity (EUAC)}

The first step to find out if Spanish largest companies understand CE the way the EU Action Plan proposes (RQ1.2) requires measuring the EU Aligned Circularity (EUAC) of companies, by assessing if the twelve variables selected after EU standards for $\mathrm{CE}$ made part of the companies' reports. The analysis would only assess whether the variable is present or not, discarding an analysis of the importance or level of information given, since that would go beyond the scope of the research and would require a different qualitative analysis (Table 6).

In order to grant the reliability of results for EUAC (Table 6), the Cronbach's Alpha coefficient for every one of the four indicators was calculated (Table 7). Although the Cronbach's Alpha coefficient does not provide a given p-value to determine the validity of the sample, the coefficients show the reliability of indicators, provided a coefficient up to 0,7 or more is normally considered acceptable for this sort of samples.

The analysis about the EUAC of the IBEX35 index companies shows that most of them report data and information about 'low environmental impact', 'energy efficiency' and 'low carbon emissions', and to a lower extent about 'waste management', 'dematerialization' and 'renewable energy'. On the contrary, almost none reported on 'industrial symbiosis', 'durability', 'eco-design' and 'live cycle analysis'. From a sectorial point of view, interesting outcomes are observed for EUAC, both at aggregated level and per variable. The Industry sector is the only one reporting on all 12 variables, followed by the Energy sector that only lacks 'durability'. On the other side, the Transport \& Logistics sector did not report on half of the variables, while the Financial services and Services sectors did not report on 5 and 4 variables respectively. Looking to the variables, the 'low environmental impact' and 'energy efficiency' topics are the most consistent ones throughout the sectors, while the 'secondary raw materials' and 'recyclability' are the topics showing a more heterogeneous behaviour.

From a preliminary observation, the EUAC aggregated results show that the Energy and Industry sectors are well above the rest, followed by the Manufacture/retail sector. Again, the Transport/ Logistics sector scores the lowest, which may appear to be unexpected, considering the high impact in carbon emissions attributable to the sector activity. On the contrary, the EUAC index for Services and Financial Services sectors shows a considerable alignment to the EU circularity approach, taking into account the low impact these sectors have in the environment.

The results from the Kruskal-Wallis test show that there are significant differences (at 5\%) in EUAC among the seven sectors. The ranks assigned by the test allow us confirming that Energy, Industry and Manufacture/retail are the sectors with highest EUAC, while Transport \& logistics, Technology and Financial services are those with lowest ranks (Table 8).

As explained before, we think that EUAC may also be influenced by other elements affecting the company activities such as their energy intensity, emissions intensity or waste and effluents intensity. Therefore, we use the Mann-Whitney test, to assess if there are significant differences in EUAC depending on each of these three variables. In relation to energy intensity, significant differences in EUAC exist at 5\% between companies with high and not high energy intensity (Table 9) and, as expected, companies with high energy intensity show higher EUAC values (average rank in Table 10). However, differences between EUAC after the emissions intensity or the waste and effluents intensity are not statistically significant (Table 9); although companies with high emissions or waste intensity show higher EUAC values (Table 10). 
Table 7

Cronbach's Alpha coefficients.

\begin{tabular}{|c|c|c|c|c|}
\hline & EUAC_R (4) & EUAC_P (4) & EUAC_Pt (4) & EUAC aggr. (12) \\
\hline Cronbach's Alpha coef. & 0,830 & 0686 & 0,742 & 0898 \\
\hline
\end{tabular}

Table 8

EUAC 7 sectors Kruskal-Wallis test ranks.

\begin{tabular}{lll}
\hline & SECTOR & Average rank \\
\cline { 2 - 3 } & Industry & 23.81 \\
\hline EUAC & Transport \& logistics & 4.00 \\
& Technology & 11.13 \\
& Financial Services & 12.67 \\
Manufacture/retail & 21.13 \\
& Energy & 25.29 \\
Services & 17.10 \\
\hline
\end{tabular}

\subsection{Companies' Reported Circularity (CRC)}

The second step to answer $\mathbf{R Q 1 . 2}$ requires assessing what the companies expressly identify and report as CE, the so-called CRC. Consequently, the companies' reports were re-analysed to find out which variables were expressly considered as CE. Table 11 does also include the CRC index associated to variables expressly considered as $C E$ per sector, to find out different behaviours related to the companies' activity.

Although all variables were referred at aggregated level, some of them show rather low percentages, as it is the case for 'industrial symbiosis', 'durability' and 'low carbon emissions'. As for the variables more frequently referred in relation to $\mathrm{CE}$, "waste management', 'recyclability' and, to a lower extent, 'secondary raw materials' are those ranking highest. From the sectorial point of view, 'technology' and 'manufacture/retail' sectors are strongly influenced by a single company within its corresponding sector which scores much higher than other companies. In fact, the two sectors would score $0 \%$ in all variables if those 'exceptional' companies were not considered, showing a much more representative image, similar to that of the Transport \& logistics, Financial Services and Services sectors. Industry and Energy are clearly the sectors reporting more about $\mathrm{CE}$, both in number of variables referred and number of companies referring to them.

The CRC index at aggregated level shows rather low percentages, significantly below the EUAC index, which accounts for the companies being actually engaged with the $C E$ variables proposed by the EU, without expressly considering them as $\mathrm{CE}$. In fact, the percentages for CRC are about half or close to half the percentages for EUAC. Provided this gap, the two sectors which ranked highest in EUAC are also ranking higher in CRC, which is consistent with the idea that those sectors are more interested in CE and, therefore, better informed about CE principles and standards and, possibly, about the EU CE Action Plan. On the contrary, the Services and Financial services sectors present a different behaviour, with very low percentages of CRC, ten and fifteen times lower than EUAC, respectively. In this case, results suggest that $\mathrm{CE}$, as such, makes no part of these companies' agenda, even though they care about some of the variables included in CE.

As with EUAC, we test the existence of significant differences in CRC, grouping companies by sector and by intensity in energy, emissions and waste-effluents. The results from Kruskal-Wallis test confirm statistically significant differences (at 5\%) in CRC among sectors. The ranks assigned by the test show higher values of CRC for companies in Industry' and Manufacture/retail sectors, and lower values for Transport \& logistics and Financial services (Table 12).

The Mann-Whitney test for CRC by energy, emissions and waste intensity reveals significant differences between high intensity and not high intensity companies for energy and emissions, at $1 \%$ and $5 \%$ respectively (Table 13 ). On the contrary, the difference in CRC by waste-effluents intensity is not significant. Average ranks confirm that companies with high intensity in energy, emissions and wasteeffluents show higher CRC values (Table 14).

The comparison of results for EUAC and CRC, stating the different perception about CE between the EU CE Action Plan and the companies reporting, can be observed at aggregated level and per variable in Table 15. It becomes clear that some variables are not perceived as CE by companies, notably those related to energy (P1, Pt4, R4 and R3) followed by Dematerialization (P2). On the contrary, Durability, Industrial symbiosis, and Recyclability variables are mostly reported as $\mathrm{CE}$, although the low percentage of companies referring these variables suggests a link to their specific activity. At aggregated level, while the degree of reporting CE variables reaches $50 \%$, the percentage of variables expressly reported as CE is less than half (18\%), highlighting the different perception of what CE is between the EU Action Plan and companies.

The correlation analysis between EUAC and CRC is presented in Table 16. Results must be considered as indicative trends rather than a sound representation of the companies' behaviour due to the limited size of the sample and the strong impact attributable to 'exceptional' companies. The aggregated indexes correlation is positive and significant ( $22=0.795)$, as could be expected. By category (resources, process and products), it is interesting to note

Table 9

EUAC Energy, emissions and waste intensity Mann-Whitney test results.

\begin{tabular}{|c|c|c|c|}
\hline EUAC & Energy intensity & Emissions intensity & Waste and effluents intensity \\
\hline U Mann-Whitney & 91.000 & 119.00 & 104.500 \\
\hline Z & -2.166 & -1.351 & -1.630 \\
\hline Asymptotic sig. & .030 & .177 & .103 \\
\hline
\end{tabular}

Table 10

EUAC Energy, emissions and waste intensity Mann-Whitney test ranks.

\begin{tabular}{|c|c|c|c|c|}
\hline & Average rank & Energy intensity & Emissions intensity & Waste and effluents intensity \\
\hline \multirow[t]{2}{*}{ EUAC } & High & 22.93 & 20.97 & 22.04 \\
\hline & No high & 15.33 & 16.29 & 16.25 \\
\hline
\end{tabular}


Table 12

CRC 7 sectors Kruskal-Wallis test ranks.

\begin{tabular}{lll}
\hline & SECTOR & Average rank \\
\cline { 2 - 3 } Industry & 25.56 \\
\hline CRC & Transport \& logistics & 8.50 \\
& Technology & 15.38 \\
& Financial Services & 12.83 \\
Manufacture/retail & 15.13 \\
& Energy & 24.86 \\
& Services & 16.70 \\
\hline
\end{tabular}

that the correlation is positive in the three cases and is much lower in the group of variables related to the company process. The highest correlation between EUAC and CRC is observed for the product category.

From the sectorial point of view (Table 17), the Technology and Energy sectors are the ones showing the highest degree of correlation, closely followed by the Manufacture \& Retail sector. The Industry and Financial services are only partially correlated, while the Services and Transport \& Logistics sectors present no correlation at all. On the other hand, the variables showing a higher level of correlation are those for products. The exception represented by the Industry sector, where the process variables score higher, suggests that industrial companies approach to $\mathrm{CE}$ is closer to EU standards in the process phase of the activity than it is for all other companies, which tend to associate $\mathrm{CE}$ as part of the product characteristics.

\subsection{Circular economy vs. environmental sustainability}

Once the actual (EUAC) and specific (CRC) engagement of companies with $\mathrm{CE}$ have been determined, their relation with the environmental sustainability reporting will answer the second research question (RQ2). The correlation between CE and environmental sustainability is analysed after EUAC and CRC indexes, and the environmental sustainability indexes produced by ESG (at aggregated level (ESG-Env) and segmented in Resource Use Score (ESG_R), Emissions Score (ESG_E) and Environmental Innovation Score (ESG_I)).

The preliminary results show no evidence of correlation between EUAC or CRC and the sustainability indexes in all cases, those at aggregated level, and those per category. To further evaluate the CE correspondence with environmental sustainability we divide the sample in two groups depending on the value for each EUAC and CRC index: above or below the median. From there, we test if there are significant differences between the ESG indexes for the two groups of companies.

The Mann-Whitney tests of differences between the ESG indexes (ESG_Env, ESG_R, ESG_E and ESG_I) in the two groups of companies (obtained after dividing the sample according to the value of EUAC index), confirm not significant differences for ESG_Env, ESG_R and ESG_E between the companies with higher/ lower EUAC, EUAC_P or EUAC_P (Table 18). However, there are significant differences (at 5\%) between ESG_I of companies with EUAC_Pt above or below the median, suggesting that companies with higher level of Environmental Innovation may score better in EUAC for the products category, meaning reporting about Ecodesign, Durability, Recyclability and Low carbon emissions linked to products.

It can be observed (Table 19) that the average rank is higher at aggregated level and at each subcategory level for the group of companies with EUAC above median values, suggesting some light correspondence between $\mathrm{CE}$ and environmental sustainability, especially at the Environmental Innovation subcategory level. 
Table 13

CRC Energy, emissions and waste intensity Mann-Whitney test results.

\begin{tabular}{|c|c|c|c|}
\hline CRC & Energy intensity & Emissions intensity & Waste and effluents intensity \\
\hline U Mann-Whitney & 67.000 & 101.500 & 129.500 \\
\hline $\mathrm{Z}$ & -3.046 & -1.995 & -.868 \\
\hline Asymptotic sig. & .002 & .046 & .385 \\
\hline
\end{tabular}

Table 14

CRC Energy, emissions and waste intensity Mann-Whitney test ranks.

\begin{tabular}{|c|c|c|c|c|}
\hline & Average rank & Energy intensity & Emissions intensity & Waste and effluents intensity \\
\hline \multirow[t]{2}{*}{$C R C$} & High & 24.53 & 22.03 & 20.32 \\
\hline & No high & 14.19 & 15.94 & 17.94 \\
\hline
\end{tabular}

If the sample is divided after the median of CRC index, the results obtained from the Mann-Whitney test (Table 20) show significant differences only for the Resources category (at 10\%).

Again, the companies with higher CRC values show slightly higher ESG values, indicating the correspondence, at aggregated level and at subcategory level, between circularity measured by CRC indexes and environmental sustainability (ESG indexes), with the exception, in opposition to EUAC, of Environmental Innovation subcategory (Table 21 ).

In order to test the robustness of results, the previous analyses are replicated using the mean instead of the median for EUAC and CRC indexes. The median is a better midpoint metric for cases where outliers could dramatically skew the mean, whereas the latter has traditionally been the most popular midpoint metric in a set. As can be seen in Table 22, significant differences (at 10\%) emerge again between ESG_I of companies with EUAC_Pt above or below the mean, reinforcing the idea that companies with higher level of Environmental Innovation may score better in EUAC for the products category.

Likewise, the average rank is higher for companies with higher EUAC levels, reaffirming the correspondence between $C E$ and environmental sustainability, especially at the Environmental Innovation subcategory level (Table 23).

The results are also coincident in relation to the CRC (Table 24). When the sample is divided after the mean of CRC index, the MannWhitney test shows significant differences only for the Resources category (at $10 \%$ ).

As can be seen in Table 25, the companies that achieve higher ESG values are also the ones that have shown higher values in their CRC indexes (except for the Environmental Innovation subcategory).

Overall, a correspondence between CE and environmental sustainability is suggested by the results in most of the categories, both regarding the engagement with the CE standards from EU and the companies own identification of CE. However, this trend is definitely not homogeneous throughout the sample, with some sectors (Energy, Industry and Manufacture/Retail) presenting a much clearer correspondence than others (Financial Services, Services and Transport/Logistics).

\section{Conclusions}

The research presented in this paper has analysed whether the CE makes part of the 36 largest Spanish companies' agenda and to what extent are the companies aligned with the CE principles and standards promoted in the EU Circular Economy Action Plan (RQ1). Given the existing debate over the overlapping of circularity and environmental sustainability, we have also analysed if companies do actually perceive and report $\mathrm{CE}$ as a component of environmental sustainability, or as a significantly different topic (RQ2).

As of now, the CE cannot be considered as a priority among the largest companies in Spain, with half of them not even reporting a single reference about it. Although the activity sector may have some influence over the company's interest on CE, especially among the most industrial and energy intensive ones, results suggest that the companies adopting CE as a priority or strategic line, have done so out of their own particular vision, values or proactivity, rather than as a response to institutional, sectorial or external pressure. From the 36 companies studied, the only four that excel in CE belong to four different sectors, with different industrial needs, society exposure and business model. It is therefore hard to accept that their decision to adopt the CE principles responds to institutional drivers and exogenous theories. Even though the EU and the Spanish Government have launched a series of programmes and strategies to promote $\mathrm{CE}$ among companies, the results suggest that companies are not institutionally driven to $\mathrm{CE}$, at least to this date, nor feeling pressure from their stakeholders. On the contrary, endogenous variable theories such as the Resource Based View theory adapt much better to this behaviour based on companies identifying the $\mathrm{CE}$ principles and practice with differentiation and competitive advantage.

At activity level, the fact that those sectors that are subject to relevant environmental impacts are more aligned with the EU standards for $\mathrm{CE}$, than those with less significant impacts, is consistent with prior literature about exposure, risk management and corporate reputation, opening the door to legitimacy and stakeholders' theories. However, the contrast found between what the companies do and what they expressly consider CE, suggests that most of them are not using $\mathrm{CE}$ as a means to reduce exposure or improve their reputation, but rather as an instrumental means to be more efficient, more competitive or distinct, again in connection to the RBV theory and not to exogenous theories. This possibility could be further investigated by analysing the presence of $C E$ in other sort of information from companies such as the management report, which focusses on investors and shareholders.

This assumption makes sense when studying what the companies perceive as CE. Looking at external pressure, sectors with close exposure to consumers such as the Services, Financial Services or Manufacture and Retail, scarcely refer to CE in their reports, even though they actually report on many of the principles and elements considered as CE by the EU Action Plan. Exogenous theories (institutional, legitimacy or stakeholders), would not explain this behaviour, whereas if CE is perceived as a source for differentiation and competitive advantage, it makes sense that these last sectors find not as much interest in $\mathrm{CE}$ as the industrial ones do.

The research has found evidence that there is a light correspondence between CE and environmental sustainability, 
Table 16

Correlation between EUAC and CRC.

\begin{tabular}{lllll}
\hline EUAC vs. CRC & Aggregated & Resources $(\mathrm{R})$ & Process $(\mathrm{P})$ & Products (Pt) \\
\hline Correlation coef. $(R)$ & 0.795 & 0.711 & 0.508 & 0.794 \\
Pearson $\left(R^{2}\right)$ & 0.632 & 0.506 & 0.258 & 0.630 \\
\hline
\end{tabular}

Table 17

Correlation between EUAC and CRC per sectors.

\begin{tabular}{|c|c|c|c|c|c|c|c|c|}
\hline \multirow[t]{2}{*}{ EUAC vs. CRC } & \multicolumn{2}{|c|}{ Aggregated } & \multicolumn{2}{|c|}{$\begin{array}{l}\text { Resources } \\
\text { (R) }\end{array}$} & \multicolumn{2}{|c|}{ Process $(\mathrm{P})$} & \multicolumn{2}{|c|}{ Products $(\mathrm{Pt})$} \\
\hline & $\overline{\mathrm{R}}$ & $R^{2}$ & $\overline{\mathrm{R}}$ & $R^{2}$ & $\bar{R}$ & $R^{2}$ & $\overline{\mathrm{R}}$ & $R^{2}$ \\
\hline 1. Industry & 0.648 & 0.420 & 0.529 & 0.280 & 0.831 & 0.690 & 0.731 & 0.535 \\
\hline 2. Trans./Logis. & - & & - & - & - & - & - & - \\
\hline 3. Technology & 0.992 & 0.984 & 0.927 & 0.860 & 0.870 & 0.758 & 0.962 & 0.926 \\
\hline 4. Fin. Services & 0.539 & 0.291 & - & - & 0.447 & 0.200 & 0.542 & 0.294 \\
\hline 5. Manuf./retail & 0.827 & 0.684 & 0.778 & 0.605 & - & - & 0.816 & 0.667 \\
\hline 6. Energy & 0.964 & 0.929 & 0.510 & 0.260 & 0.867 & 0.752 & 0.966 & 0.933 \\
\hline 7. Services & -0.057 & 0.003 & - & - & - & - & 0.764 & 0.583 \\
\hline
\end{tabular}

especially in specific categories such as environmental innovation or industrial process. Companies report on environmental sustainability as part of their whole sustainability strategy under a framework of normative, instrumental, legitimacy or reputational strategy and, thus, the reported information connects to social/ economic sustainability, and responds to many stakeholders. The research results show that this is not the case for $\mathrm{CE}$, which in most cases is reported in an isolated way, targeting very specific issues, confirming Geissdoerfer et al. (2017) and Stewart and Niero (2018) assumption that sustainability and CE are not substitute or equivalent concepts. Whereas we agree with Ellen MacArthur Foundation (2013) and Ghisellini et al. (2016) on CE being an economic model that contributes to achieving sustainability, our results refute the idea that, as of now, CE can be considered as a purpose to be pursued per se in many reports (Stewart and Niero, 2018). On the contrary, in most cases it appears to be pursued without being reported as such.

The analyses performed are mostly descriptive, given the size of the sample, and have limited statistical significance. However, the results present trends and signs of how CE is being perceived and adopted in large companies, which are those counting with resources, funds and institutional support (Aranda-Usón et al., 2019). These trends suggest that the EU CE Action Plan is failing to reach the companies attention and interest, and that CE is possibly lacking the necessary pressure from stakeholders to gain priority among companies. Besides, the research sample is limited, and should not be considered as a fair representation of all Spanish companies. Although most of the largest companies in Europe present similar behaviors in this field, other factors such as local norms, culture and values may have an impact in the companies' engagement in circularity. Studying which actions could be taken by policy makers to bring CE closer to the large companies, could also be an interesting and useful line for research.

Other potential lines for further research could extend the sample to more companies and countries to evaluate if the results are similar or they are subject to other drivers linked to size, country, context, etc. In this regard, it must be borne in mind that the main source of data used in this study has been the information publicly transmitted by the companies through their annual reports, sustainability reports, CSR reports, etc. Researchers have manually detected and accounted for direct and indirect references to $\mathrm{CE}$ and have assessed the relevance given to $\mathrm{CE}$ by the company looking at the specific section of the report in which it appears, thus ranking the weight of such mentions. Compared to the use of 
Table 18

ESG Mann-Whitney test results grouping EUAC median variables.

\begin{tabular}{|c|c|c|c|c|}
\hline & $\begin{array}{l}\text { Aggregated Environmental (ESG_Env)- } \\
\text { (EUAC) }\end{array}$ & $\begin{array}{l}\text { Resources (ESG_R)- } \\
\text { (EUAC_R) }\end{array}$ & $\begin{array}{l}\text { Emissions/Process (ESG_E)- } \\
\text { (EUAC_P) }\end{array}$ & $\begin{array}{l}\text { Environmental Innovation/Products (ESG_I)- } \\
\text { (EUAC_Pt) }\end{array}$ \\
\hline $\begin{array}{l}\text { U Mann- } \\
\text { Whitney }\end{array}$ & 128.000 & 110.000 & 113.000 & 38.000 \\
\hline $\mathrm{Z}$ & -.288 & -1.127 & -1.023 & -2.408 \\
\hline Asymptotic sig. & .773 & .260 & .306 & .016 \\
\hline
\end{tabular}

Table 19

ESG Mann-Whitney test ranks grouping EUAC median variables.

\begin{tabular}{|c|c|c|c|c|}
\hline & \multicolumn{4}{|l|}{ Average rank } \\
\hline & $\begin{array}{l}\text { Aggregated Environmental (ESG_Env)- } \\
\text { (EUAC) }\end{array}$ & $\begin{array}{l}\text { Resources (ESG_R)- } \\
\text { (EUAC_R) }\end{array}$ & $\begin{array}{l}\text { Emissions/Process (ESG_E)- } \\
\text { (EUAC_P) }\end{array}$ & $\begin{array}{l}\text { Environmental Innovation/Products (ESG_I)- } \\
\text { (EUAC_Pt) }\end{array}$ \\
\hline EUACs $<$ median & 16.50 & 15.79 & 15.95 & 15.41 \\
\hline EUACs $>$ median & 17.47 & 19.67 & 19.47 & 25.57 \\
\hline
\end{tabular}

Table 20

ESG Mann-Whitney test results grouping CRC median variables.

\begin{tabular}{|c|c|c|c|c|}
\hline & $\begin{array}{l}\text { Aggregated Environmental (ESG_Env)- } \\
\text { (CRC) }\end{array}$ & $\begin{array}{l}\text { Resources (ESG_R)- } \\
\left(\mathrm{CRC} \_R\right)\end{array}$ & $\begin{array}{l}\text { Emissions/Process (ESG_E)- } \\
(\text { CRC_P) }\end{array}$ & $\begin{array}{l}\text { Environmental Innovation/Products (ESG_I) } \\
\text { (CRC_Pt) }\end{array}$ \\
\hline $\begin{array}{l}\text { U Mann- } \\
\text { Whitney }\end{array}$ & 111.000 & 80.000 & 112.000 & 128.000 \\
\hline $\mathrm{Z}$ & -.901 & -1.712 & -1.058 & -.503 \\
\hline Asymptotic sig. & .368 & .087 & .290 & 0.615 \\
\hline
\end{tabular}

Table 21

ESG Mann-Whitney test ranks grouping CRC median variables.

\begin{tabular}{|c|c|c|c|c|}
\hline & \multicolumn{4}{|l|}{ Average rank } \\
\hline & $\begin{array}{l}\text { Aggregated Environmental (ESG_Env)- } \\
\text { (CRC) }\end{array}$ & $\begin{array}{l}\text { Resources (ESG_R)- } \\
\left(\mathrm{CRC} \_R\right)\end{array}$ & $\begin{array}{l}\text { Emissions/Process (ESG_E)- } \\
\text { (CRC_P) }\end{array}$ & $\begin{array}{l}\text { Environmental Innovation/Products (ESG_I) } \\
\text { (CRC_Pt) }\end{array}$ \\
\hline CRCs $<$ median & 15.44 & 15.48 & 15.89 & 18.26 \\
\hline CRCs $>$ median & 18.47 & 21.73 & 19.53 & 16.53 \\
\hline
\end{tabular}

Table 22

ESG Mann-Whitney test results grouping EUAC mean variables.

\begin{tabular}{|c|c|c|c|c|}
\hline & $\begin{array}{l}\text { Aggregated Environmental (ESG_Env)- } \\
\text { (EUAC) }\end{array}$ & $\begin{array}{l}\text { Resources (ESG_R)- } \\
\text { (EUAC_R) }\end{array}$ & $\begin{array}{l}\text { Emissions/Process (ESG_E)- } \\
\text { (EUAC_P) }\end{array}$ & $\begin{array}{l}\text { Environmental Innovation/Products (ESG_I)- } \\
\text { (EUAC_Pt) }\end{array}$ \\
\hline $\begin{array}{l}\text { U Mann- } \\
\text { Whitney }\end{array}$ & 124.000 & 110.000 & 113.000 & 85.500 \\
\hline $\mathrm{Z}$ & -.221 & -1.127 & -1.023 & -1.809 \\
\hline Asymptotic sig. & .825 & .260 & .306 & .070 \\
\hline
\end{tabular}

Table 23

ESG Mann-Whitney test ranks grouping EUAC mean variables.

\begin{tabular}{|c|c|c|c|c|}
\hline & \multicolumn{4}{|l|}{ Average rank } \\
\hline & $\begin{array}{l}\text { Aggregated Environmental (ESG_Env)- } \\
\text { (EUAC) }\end{array}$ & $\begin{array}{l}\text { Resources (ESG_R)- } \\
\text { (EUAC_R) }\end{array}$ & $\begin{array}{l}\text { Emissions/Process (ESG_E)- } \\
\text { (EUAC_P) }\end{array}$ & $\begin{array}{l}\text { Environmental Innovation/Products (ESG_I)- } \\
\text { (EUAC_Pt) }\end{array}$ \\
\hline EUACs $<$ mean & 16.54 & 15.79 & 15.95 & 15.07 \\
\hline EUACs $>$ mean & 17.30 & 19.67 & 19.47 & 21.42 \\
\hline
\end{tabular}

specific software, this manual process has advantages, such as the possibility of including or not including references at the discretion of the researcher, and drawbacks, such as the slowness and cost of the process. 
Table 24

ESG Mann-Whitney test results grouping CRC mean variables.

\begin{tabular}{|c|c|c|c|c|}
\hline & $\begin{array}{l}\text { Aggregated Environmental (ESG_Env)- } \\
\text { (CRC) }\end{array}$ & $\begin{array}{l}\text { Resources (ESG_R)- } \\
\text { (CRC_R) }\end{array}$ & $\begin{array}{l}\text { Emissions/Process (ESG_E)- } \\
\text { (CRC_P) }\end{array}$ & $\begin{array}{l}\text { Environmental Innovation/Products (ESG_I)- } \\
\text { (CRC_Pt) }\end{array}$ \\
\hline $\begin{array}{l}\text { U Mann- } \\
\text { Whitney }\end{array}$ & 93.000 & 80.000 & 112.000 & 128.000 \\
\hline $\mathrm{Z}$ & -1.363 & -1.712 & -1.058 & -.503 \\
\hline Asymptotic sig. & .173 & .087 & .290 & 0.615 \\
\hline
\end{tabular}

Table 25

ESG Mann-Whitney test ranks grouping CRC mean variables.

\begin{tabular}{|c|c|c|c|c|}
\hline & \multicolumn{4}{|l|}{ Average rank } \\
\hline & $\begin{array}{l}\text { Aggregated Environmental (ESG_Env)- } \\
\text { (CRC) }\end{array}$ & $\begin{array}{l}\text { Resources (ESG_R)- } \\
\left(\mathrm{CRC} \_R\right)\end{array}$ & $\begin{array}{l}\text { Emissions/Process (ESG_E)- } \\
\text { (CRC_P) }\end{array}$ & $\begin{array}{l}\text { Environmental Innovation/Products (ESG_I)- } \\
\text { (CRC_Pt) }\end{array}$ \\
\hline CRCs $<$ mean & 15.15 & 15.48 & 15.89 & 18.26 \\
\hline CRCs $>$ mean & 19.85 & 21.73 & 19.53 & 16.53 \\
\hline
\end{tabular}

\section{Author credit statement}

All authors have equally contributed to the paper in its design, research and writing.

\section{ANNEX 1}

\begin{tabular}{|c|c|c|c|c|c|}
\hline \multicolumn{2}{|c|}{ Company } & \multirow{2}{*}{$\begin{array}{l}\text { Activity Sector } \\
\text { Industry (1) }\end{array}$} & \multirow{2}{*}{$\begin{array}{l}\text { Energy intensity } \\
\text { High }\end{array}$} & \multirow{2}{*}{$\begin{array}{l}\text { Emissions intensity } \\
\text { High }\end{array}$} & \multirow{2}{*}{$\begin{array}{l}\text { Waste-effluents intensity } \\
\text { High }\end{array}$} \\
\hline 1 & Acciona & & & & \\
\hline 2 & Acerinox & Industry (1) & High & High & High \\
\hline 3 & ACS & Industry (1) & High & High & High \\
\hline 4 & AENA & Transport/Logistics (2) & Not High & Not High & Not High \\
\hline 5 & Amadeus & Technology (3) & Not High & Not High & Not High \\
\hline 6 & Arcelormital & Industry (1) & High & High & High \\
\hline 7 & B. Sabadell & Financial services (4) & Not High & Not High & Not High \\
\hline 8 & B. Santander & Financial services (4) & Not High & Not High & Not High \\
\hline 9 & Bankia & Financial services (4) & Not High & Not High & Not High \\
\hline 10 & Bankinter & Financial services (4) & Not High & Not High & Not High \\
\hline 11 & $B B V A$ & Financial services (4) & Not High & Not High & Not High \\
\hline 12 & Caixabank & Financial services (4) & Not High & Not High & Not High \\
\hline 13 & Cellnex & Technology (3) & Not High & High & Not High \\
\hline 14 & CIE Automotive & Industry (1) & High & Not High & Not High \\
\hline 15 & Dia & Manufacture/Retail (5) & Not High & Not High & High \\
\hline 16 & Enagas & Energy (6) & High & High & Not High \\
\hline 17 & ENCE & Energy (6) & High & High & High \\
\hline 18 & Endesa & Energy (6) & High & High & Not High \\
\hline 19 & Ferrovial & Industry (1) & High & High & High \\
\hline 20 & Grifols & Manufacture/Retail (5) & Not High & Not High & High \\
\hline 21 & $I A G$ & Transport/Logistics (2) & High & High & Not High \\
\hline 22 & Iberdrola & Energy (6) & High & High & Not High \\
\hline 23 & Inditex & Manufacture/Retail (5) & Not High & Not High & Not High \\
\hline 24 & Indra & Technology (3) & Not High & High & High \\
\hline 25 & Inm. Colonial & Services (7) & Not High & Not High & Not High \\
\hline 26 & Mapfre & Services (7) & Not High & Not High & Not High \\
\hline 27 & Mediaset & Services (7) & Not High & Not High & Not High \\
\hline 28 & Meliá & Services (7) & Not High & Not High & High \\
\hline 29 & Merlin & Services (7) & Not High & Not High & High \\
\hline 30 & Naturgy & Energy (6) & High & High & Not High \\
\hline 31 & REC & Energy (6) & Not High & High & Not High \\
\hline 32 & Repsol & Energy (6) & High & High & High \\
\hline 33 & Siemens & Industry (1) & Not High & Not High & Not High \\
\hline 34 & T. Reunidas & Industry (1) & High & High & High \\
\hline 35 & Telefónica & Technology (3) & Not High & Not High & Not High \\
\hline 36 & Viscofan & Manufacture/Retail (5) & High & High & High \\
\hline
\end{tabular}

\section{Declaration of competing interest}

The authors declare that they have no known competing financial interests or personal relationships that could have appeared to influence the work reported in this paper. 


\section{References}

Acerete, B., Llena, F., Moneva, J.M., 2011. Environmental disclosure in financial statements: An analysis of Spanish toll motorway concessionaires. Transport. Res. Transport Environ. 16 (7), 377-383. https://doi.org/10.1016/ j.trd.2011.02.005.

Acerete, B., Gasca, M., Llena, F., 2019. Analysis of environmental financial reporting in the Spanish toll roads sector. Spanish Journal of Finance and Accounting/ Revista Española de Financiación y Contabilidad 48 (4), 430-463. https:// doi.org/10.1080/02102412.2019.1591880.

AECA, 2003. Marco conceptual de la Responsabilidad Social Corporativa, 61. Asociación Española de Contabilidad y Administración de Empresas.

Aranda-Usón, A., Portillo-Tarragona, P., Marín-Vinuesa, L.M., Scarpellini, S., 2019. Financial resources for the circular Economy : A perspective from businesses. Sustainability 11 (888), 1-23. https://doi.org/10.3390/su11030888.

Barney, J., 1991. Firm resources and sustained competitive advantage. J. Manag. 17 (1), 99-120. https://doi.org/10.1177/014920639101700108.

Barney, J.B., 2001b. Resource-based theories of competitive advantage: A ten-year retrospective on the resource-based view. J. Manag. https://doi.org/10.1177/ 014920630102700602.

Barney, J.B., Arikan, A.M., 2008. The resource-based view: Origins and implications. In: The Blackwell Handbook of Strategic Management. https://doi.org/10.1111/ b.9780631218616.2006.00006.x.

Barreto, I., 2010. Dynamic Capabilities: A review of past research and an agenda for the future. J. Manag. 36 (1), 256-280. https://doi.org/10.1177/ 0149206309350776.

Bebbington, J., Unerman, J., O’Dwyer, B., 2014. Sustainability Accounting and Accountability. Routledge.

Bocken, N.M.P., Miller, K., Weissbrod, I., Holgado, M., Evans, S., 2017a. Business model experimentation for circularity: Driving sustainability in a large international clothing retailer. Econ. Pol. Energy Environ. 2017 (1), 85-122. https:// doi.org/10.3280/EFE2017-001006.

Bocken, N.M.P., Ritala, P., Huotari, P., 2017b. The circular economy: Exploring the introduction of the concept among S\&P 500 firms. J. Ind. Ecol. 21 (3), 487-490. https://doi.org/10.1111/jiec.12605.

Bromiley, P., Rau, D., 2016. Operations management and the resource based view: Another view. J. Oper. Manag. 41, 95-106. https://doi.org/10.1016/ j.jom.2015.11.003.

Campbell, J.L., 2007. Why would corporations behave in socially responsible ways? An institutional theory of corporate social responsibility. Acad. Manag. Rev. 32 (3), 946-967.

Cepeda, G., Vera, D., 2007. Dynamic capabilities and operational capabilities: A knowledge management perspective. J. Bus. Res. 60 (8), 426-437. https:// doi.org/10.1016/j.jbusres.2007.01.013.

Clarkson, P.M., Li, Y., Richardson, G.D., Vasvari, F.P., 2008. Revisiting the relation between environmental performance and environmental disclosure: An empirical analysis. Account. Org. Soc. 33 (4), 303-327.

COTEC, 2017. SITUACIÓN Y EVOLUCIÓN DE LA ECONOMÍA CIRCULAR EN ESPAÑA. Fundación COTEC para la Innovación, ISBN 978-84-92933-35-8. http:// informecotec.es/media/informe-CotecISBN-1.pdf.

Daddi, T., Ceglia, D., Bianchi, G., de Barcellos, M., 2019. Paradoxical tensions and corporate sustainability: A focus on circular economy business cases. Corp. Soc. Responsib. Environ. Manag. 26, 4. https://doi.org/10.1002/csr.1719.

De los Rios, I.C., Charnley, F.J.S., 2017. Skills and capabilities for a sustainable and circular economy: The changing role of design. J. Clean. Prod. 160, 109-122. https://doi.org/10.1016/j.jclepro.2016.10.130.

Deegan, C., 2002. The legitimising effect of social and environmental disclosures-a theoretical foundation. Accounting. Auditing \& Accountability Journal 15 (3), $282-311$.

Deegan, Craig, 2017. Twenty five years of social and environmental accounting research within Critical Perspectives of Accounting: Hits, misses and ways forward. Crit. Perspect. Account. 43, 65-87. https://doi.org/10.1016/ j.cpa.2016.06.005.

DiMaggio, P.J., Powell, W.W., 1983. DiMaggio and Powell_1983_The iron cage revisited: Institutional isomorphism and collective rationality in organizational fields. Am. Socio. Rev. 48 (2), 147-160.

Elia, V., Gnoni, M.G., Tornese, F., 2017. Measuring circular economy strategies through index methods: A critical analysis. J. Clean. Prod. 142, 2741-2751. https://doi.org/10.1016/j.jclepro.2016.10.196.

Ellen MacArthur Foundation, 2013. Towards a Circular Economy. Economic and Business Rationales for an Accelerated Transition. Ellen MacArthur Foundation, 1. Ellen McArthur Foundation. Retrieved from. https://www. ellenmacarthurfoundation.org/assets/downloads/publications/EllenMacArthur-Foundation-Towards-the-Circular-Economy-vol.1.pdf.

European Commision, 2015. Communication Form the Commission to the European Parliament, the Council, the European Economic and Social Committee of the Regions - Cloosing the Loop -An EU Action Plan for the Circular Economy. COM/ 2015/0614 final. COM/2015/0614 Final. Bussels: European Commission.

Gallego-Álvarez, P.I., Ortas, P.E., 2017. Corporate environmental sustainability reporting in the context of national cultures: A quantile regression approach. Int. Bus. Rev. 26 (2), 337-353. https://doi.org/10.1016/J.IBUSREV.2016.09.003.

Gallopin, G., 1994. Impoverishment and Sustainable Development. A Systems Approach. Canada: HSD. http://www.iisd.org/pdf/impoverishment_and_sd.pdf.

Geissdoerfer, M., Savaget, P., Bocken, N.M.P., Hultink, E.J., 2017. The Circular
Economy - A new sustainability paradigm? J. Clean. Prod. 143, 757-768. https://doi.org/10.1016/j.jclepro.2016.12.048.

Geissdoerfer, M., Morioka, S.N., Monteiro de Carvalho, M., Evans, S., 2018. Business models and supply chains for the circular economy. J. Clean. Prod. 190, 712-721. https://doi.org/10.1016/j.jclepro.2018.04.159, 0959-6526.

Ghisellini, P., Cialani, C., Ulgiati, S., 2016. A review on circular economy: The expected transition to a balanced interplay of environmental and economic systems. J. Clean. Prod. 114 (1), 11-32. https://doi.org/10.1016/j.jclepro.2015.09.007.

Ghisellini, P., Ji, X., Liu, G., Ulgiati, S., 2018. Evaluating the transition towards cleaner production in the construction and demolition sector of China: a review. J. Clean. Prod. 195, 418-434. https://doi.org/10.1016/j.jclepro.2018.05.084.

Gray, R., Adams, C., Owen, D., 2018. Social and environmental accounting. In: The Routledge Companion to Critical Accounting. https://doi.org/10.4324/ 9781315775203-14.

Hahn, T., Figge, F., Pinkse, J., Preuss, L., 2017. A paradox perspective on corporate sustainability: Descriptive, instrumental, and normative aspects. J. Bus. Ethics $148,235-248$.

Haniffa, R.M., Cooke, T.E., 2005. The impact of culture and governance on corporate social reporting. J. Account. Publ. Pol. 24 (5), 391-430.

Higgins, C., Larrinaga-González, C., 2014. 16 Sustainability reporting. Sustainability Accounting and Accountability 273.

Jones, P., Comfort, D., 2017. Towards the circular economy: A commentary on corporate approaches and challenges. J. Publ. Aff. 17 (4), 1-5. https://doi.org/ 10.1002/pa.1680.

Katz-Gerro, T., López-Sintas, J., 2019. Mapping circular economy activities in the European Union: Patterns of implementation and their correlates in small and medium-sized enterprises. Bus. Strat. Environ. 28 (4), 485-496. https://doi.org/ 10.1002/bse.2259.

Kirchherr, J., Reike, D., Hekkert, M., 2017. Conceptualizing the circular economy: An analysis of 114 definitions. Resour. Conserv. Recycl. 127 (September), 221-232. https://doi.org/10.1016/j.resconrec.2017.09.005.

Larrinaga, C., Carrasco, F., Correa, C., Llena, F., Moneva, J., 2002. Accountability and accounting regulation: The case of the Spanish environmental disclosure standard. Eur. Account. Rev. 11 (4), 723-740.

Lieder, M., Rashid, A., 2016. Towards circular economy implementation: A comprehensive review in context of manufacturing industry. J. Clean. Prod. 115, 36-51. https://doi.org/10.1016/j.jclepro.2015.12.042.

Linder, M., Williander, M., 2017. Circular business model innovation: inherent uncertainties. Bus. Strat. Environ. 26 (2), 182-196. https://doi.org/10.1002/ bse.1906.

Llena, F., Talalweh, M., 2015. Factors determining social and environmental performance of islamic Companies :, Analysis of sustainability related reporting practices. Jordan Journal of Business Administration 11 (4), 981. https://doi.org/ 10.35516/0338-011-004-010.

Llena, F., Moneva, J.M., Hernandez, B., 2007. Environmental disclosures and compulsory accounting standards: The case of Spanish annual reports. Bus. Strat. Environ. 16 (1), 50-63. https://doi.org/10.1002/bse.466.

Lockett, A., Thompson, S., 2001. The resource-based view and economics. J. Manag. 27 (6), 723-754. https://doi.org/10.1016/S0149-2063(01)00121-0.

Marco-Fondevila, M., Moneva Abadía, J.M., Scarpellini, S., 2018. CSR and Green Economy: Determinants and Correlation of Firms' Sustainable Development. Corporate Social Responsibility and Environmental Management, pp. 1-16. https://doi.org/10.1002/csr.1492. July 2017.

Mathews, J.A., Tan, H., 2011. Progress toward a circular economy in China. J. Ind. Ecol. 15 (3), 435-457. https://doi.org/10.1111/j.1530-9290.2011.00332.x.

MINEICO, 2018. España Circular 2030, Estrategia Española de Economía Circular. https://www.miteco.gob.es/images/es/180206economiacircular_tcm30440922.pdf.

Moneva, J.M., Portillo-Tarragona, M.P., Llena-Macarulla, F., Scarpellini, S., 2018. Perspectivas e Impacto de la Economía Circular en Aragón desde la Óptica Empresarial. Economía Aragonesa 66, 111-126.

Pomponi, F., Moncaster, A., 2016. Circular economy for the built environment: A research framework. J. Clean. Prod. 143, 710-718. https://doi.org/10.1016/ j.jclepro.2016.12.055.

Portillo-Tarragona, P., Scarpellini, S., Llena, F., Aranda-Usón, A., 2017. Nivel de implantación de la economía circular en Aragón, 1-118. Retrieved from. https:/ www.aragon.es/estaticos/GobiernoAragon/OrganosConsultivos/ ConsejoEconomicoSocialAragon/Areas/Publicaciones/ESTUDIOS/2017/ Economia_circular_Ed_integra.pdf.

Portillo-Tarragona, P., Scarpellini, S., Moneva, J.M., Valero-Gil, J., Aranda-Usón, A., 2018. Classification and measurement of the firms' resources and capabilities applied to eco-innovation projects from a resource-based view perspective. Sustainability 10 (9). https://doi.org/10.3390/su10093161.

Potting, J., Hekkert, M., Worrell, E., Hanemaaijer, A., 2017. Circular Economy: Measuring Innovation in the Product Chain (January). http://www.pbl.nl/sites/ default/files/cms/publicaties/pbl-2016-circular-economy-measuring-innovation-in-product-chains-2544.pdf.

Prieto-Sandoval, V., Jaca, C., Ormazabal, M., 2018. Towards a consensus on the circular economy. J. Clean. Prod. 179, 605-615. https://doi.org/10.1016/j.jclepro.2017.12.224. ISSN 0959-6526.

Prieto-Sandoval, V., Jaca, C., Santos, J., Baumgartner, R.J., Ormazabal, M., 2019. Key Strategies, Resources, and Capabilities for Implementing Circular Economy in Industrial Small and Medium Enterprises. Corp Soc Resp Env Ma, pp. 1-12.

Qiu, Y., Shaukat, A., Tharyan, R., 2016. Environmental and social disclosures: Link with corporate financial performance. Br. Account. Rev. 48 (1) https://doi.org/ 
10.1016/j.bar.2014.10.007.

Rosa, P., Sassanelli, C., Terzi, S., 2019. Towards Circular Business Models: a systematic literature review on classification frameworks and archetypes. J. Clean. Prod. 236, 117696. https://doi.org/10.1016/j.jclepro.2019.117696, 0959-6526.

Sauvé, S., Bernard, S., Sloan, P., 2016. Environmental sciences, sustainable development and circular economy: Alternative concepts for trans-disciplinary research. Environmental Development 17, 48-56. https://doi.org/10.1016/ j.envdev.2015.09.002.

Scarpellini, S., Marín-Vinuesa, L.M., Aranda-Usón, A., Portillo-Tarragona, P., 2020. Dynamic capabilities and environmental accounting for the circular economy in businesses. Sustainability Accounting, Management and Policy Journal 11 (7). https://doi.org/10.1108/SAMPJ-04-2019-0150 ahead-of-print.

Schaltegger, S., Burritt, R., 2017. Contemporary environmental accounting: issues, concepts and practice. Retrieved from. https://books.google.com/books? $\mathrm{hl}=\mathrm{es} \& \mathrm{lr}=\& \mathrm{id}=$ SqOODwAAQBAJ\&oi=fnd \&pg =PA9\&dq=environmental + accounting \&ots $=i$ BUH1 1 4Png $\&$ sig $=$ ngANSHwZORIOTD1 v6GJLImG $\mathrm{p}$ XI.

Schulz, C., Hjaltadóttir, R.E., Hild, P., 2019. Practising circles: studying institutional change and circular economy practices. J. Clean. Prod. 237, 117749. https:// doi.org/10.1016/j.jclepro.2019.117749. ISSN 0959-6526.

Scott, W.R., 1995. Institutions and Organizations: Foundations for Organizational Science. Legal Theory. https://doi.org/10.1017/S1352325200000288.
Scott, W. Richard, 2014. Institutions and Organizations: Ideas, Interests and Identities. Sage. https://doi.org/10.3917/mana.202.0204.

Stewart, R., Niero, M., 2018. Circular Economy in Corporate Sustainability Strategies: A Review of Corporate Sustainability Reports in the Fast-Moving Consumer Goods Sector. Business Strategy and the Environment, pp. 1-18. https://doi.org/ 10.1002/bse.2048. December 2017.

Svensson, N., Funck, E., 2019. Management control in circular economy. Exploring and theorizing the adaptation of management control to circular business models. J. Clean. Prod. 233, 390-398. https://doi.org/10.1016/j.jclepro.2019.06.089. ISSN 0959-6526.

Teece, D.J., Pisano, G., Shuen, A., 2009. Dynamic capabilities and strategic management. In: Knowledge and Strategy. https://doi.org/10.1142/9789812796929 0004.

Urbinati, A., Chiaroni, D., Chiesa, V., 2017. Towards a new taxonomy of circular economy business models. J. Clean. Prod. 168, 487-498. https://doi.org/10.1016/ j.jclepro.2017.09.047.

Wernerfelt, B., 1984. A resource-based view of the firm. Strat. Manag. J. 5 (2), 171-180. https://doi.org/10.1002/smj.4250050207.

Zaman Mir, M., Chatterjee, B., Shiraz Rahaman, A., 2009. Culture and corporate voluntary reporting. Manag. Audit J. 24 (7), 639-667. https://doi.org/10.1108/ 02686900910975369. 